\title{
CzŁonkostwo Polski w Lidze Narodów - ASPEKTY PRAWNE
}

\section{Wstęp}

W 2020 r. mija sto lat od utworzenia Ligi Narodów i podjęcia przez nią działalności. W dniu 10 stycznia 1920 r. wszedł w życie Pakt Ligi Narodów ustanawiający podstawy prawne funkcjonowania organizacji ${ }^{1}$. Powstanie Ligi Narodów rozpoczęło nowy etap w procesie instytucjonalizacji stosunków międzynarodowych, zapoczątkowanym w drugiej połowie XIX w. i związanym z tworzeniem organizacji międzynarodowych, które zajmowały się sprawami współpracy w określonych dziedzinach, głównie o charakterze technicznym, nie wkraczając w relacje polityczne między państwami członkowskimi². Postanowiono bowiem powołać do życia organizację o kompetencjach ogólnych, w celu „rozwoju współdziałania narodów oraz zapewnienia im pokoju i bezpieczeństwa" (preambuła Paktu). Duże straty ludzkie i materialne poniesione przez państwa podczas I wojny światowej spowodowały, że idea utworzenia organizacji, która zapobiegałaby w przyszłości wybuchowi wojny, uzyskała poparcie

\footnotetext{
* Prof., dr hab., Uniwersytet Marii Curie-Skłodowskiej w Lublinie, e-mail: aprzyborowska@poczta.umcs.lublin.pl, https://www.orcid.org/0000-0002-9670-4103

1 Tekst Paktu Ligi Narodów stanowił część pierwszą Traktatu pokoju między Mocarstwami Sprzymierzonemi i Skojarzonemi a Niemcami, Wersal, 23 czerwca 1919 r., Dz. U. z 1920 r. nr 35 poz. 200; Pakt został w nim opublikowany pod tytułem Umowa Związku Narodów.

2 J. Menkes, A. Wasilkowski, Organizacje międzynarodowe. Prawo instytucjonalne, Warszawa 2017, s. 107-109.
} 
środowisk politycznych i intelektualnych $\mathrm{w}$ wielu państwach ${ }^{3}$. Idea ta została też wyrażona w ostatnim punkcie słynnych "Czternastu Punktów" prezydenta Stanów Zjednoczonych Ameryki Thomasa Woodrowa Wilsona, zawartych w orędziu wygłoszonym w Kongresie 8 stycznia 1918 r., zgodnie z którym:

Winno być utworzone powszechne zrzeszenie narodów na podstawie uroczystych umów celem dania wszystkim Państwom, wielkim i małym, wzajemnych gwarancji niezawisłości politycznej i całości terytorialnej.

Model przyszłej organizacji był prezentowany w różnych projektach, które wywoływały liczne kontrowersje i spory między państwami, ale jego ostateczny kształt określony w postanowieniach traktatowych stanowił swoisty kompromis między francuską koncepcją organizacji opartej na sile wojskowej a koncepcją anglosaską, w której pozycja Ligi Narodów wynikałaby przede wszystkim z jej autorytetu moralnego i zapewnienia wzajemnego poszanowania przez państwa członkowskie przysługujących im praw ${ }^{5}$. Projekt Paktu przygotowany przez Komisję Ligi Narodów (tzw. Komisję Crillon) został zaakceptowany 14 lutego 1918 r., a następnie $\mathrm{w}$ wersji uwzględniającej wniesione poprawki został jednogłośnie przyjęty 28 kwietnia 1919 r. podczas plenarnego posiedzenia Konferencji Pokojowej w Paryżu ${ }^{6}$. Włączono go do Traktatu pokoju z Niemcami, podpisanego w Wersalu 28 czerwca 1919 r., a także do pozostałych traktatów pokojowych. Pakt nie został ratyfikowany przez Stany Zjednoczone w związku z niewyrażeniem zgody na jego ratyfikację przez amerykański Senat ${ }^{7}$. Skomplikowało to rozpoczęcie działalności przez Ligę, ponieważ zgodnie z art. 5 ust. 3 Paktu prezydent Stanów Zjednoczonych Ameryki

3 Szerzej na temat genezy Ligi Narodów m.in. S. Sierpowski, Geneza Ligi Narodów, Dzieje Najnowsze 1999, t. 31, nr 1, s. 19-45 i tenże, Narodziny Ligi Narodów. Powstanie, organizacja i zasady działania, Poznań 1984, s. 50-72.

4 Orędzie Prezydenta W. Wilsona do Kongresu Stanów Zjednoczonych formułujące warunki pokoju (tzw. 14 Punktów), Waszyngton, 8 stycznia 1918 r., w: Wybór źródet do nauki prawa międzynarodowego, oprac. B. Winiarski, Warszawa 1938, s. 142-144.

5 W. Michowicz, Polska w Lidze Narodów, Sprawy Międzynarodowe 1978, nr 12, s. 132. Por. też J. Reginia-Zacharski, Liga Narodów, w: Liga Narodów, ONZ, NATO, UE, KBWE/ OBWE, organizacje pozarządowe, red. P. Żurawski vel. Grajewski, Łódź 2004, s. 16-24.

6 Przebieg prac nad Paktem Ligi Narodów przedstawił S. Sierpowski, Narodziny Ligi Narodów..., s. 78-99.

7 Tamże, s. 125-131. 
miał zwołać pierwsze posiedzenia Zgromadzenia i Rady Ligi. Zadania te wypełnił amerykański Departament Stanu.

\section{Stosunek Polski do idei utworzenia Ligi Narodów}

Idea utworzenia organizacji, na której byłby oparty system bezpieczeństwa międzynarodowego, wydawała się atrakcyjna dla wielu państw boleśnie doświadczonych światowym konfliktem. W szczególnej sytuacji była Polska, odradzająca się po okresie rozbiorów i państwowego niebytu. Warto przypomnieć, że w „Czternastu Punktach” prezydenta Wilsona przed punktem dotyczącym Ligi Narodów wyrażono przekonanie, że

Winno być utworzone Państwo Polskie obejmujące terytoria zamieszkałe przez ludność niewątpliwie polską; będzie mu zapewniony wolny dostęp do morza; jego niezawisłość polityczna i gospodarcza, jego całość terytorialna winny być zagwarantowane przez umowy międzynarodowe.

W ówczesnej sytuacji zdawano sobie sprawę z tego, że oprócz zbudowania systemu administracyjnego i politycznego oraz podejmowania działań na rzecz rozwoju gospodarczego dla niepodległego państwa polskiego istotne znaczenie będą miały też stosunki międzynarodowe, w szczególności nienaruszalność i bezpieczeństwo granic, dobre stosunki z sąsiadami, realizacja strategicznych założeń polityki zagranicznej i odzyskanie należnego Polsce miejsca w Europie i na świecie. Polskie władze państwowe nie mogły zatem pozostawać obojętne zarówno wobec prac paryskiej Konferencji Pokojowej, jak i udziału Polski w przyszłej organizacji międzynarodowej ${ }^{8}$. Zabierając głos podczas tej Konferencji, 25 stycznia 1919 r. delegat Polski Roman Dmowski poparł projekt rezolucji dotyczącej utworzenia Ligi Narodów, mówiąc: „Wyrażam wdzięczność w imieniu kraju, który więcej niż jakikolwiek inny potrzebuje międzynarodowych rękojmi pokoju i który przyjmie projekt Ligi Narodów

8 E. Lesiewicz, P. Stachowiak, Polska wizja Ligi Narodów, w: Polska w instytucjach międzynarodowych w latach 1918-2018, red. E. Haliżak, T. Łoś-Nowak, A. Potyrała, J. Starzyk-Sulejewska, Warszawa 2019, s. 83-84. 
z największą radością" ${ }^{\prime \prime}$. Roman Dmowski został 6 lutego 1919 r. włączony do składu Komisji Ligi Narodów.

W okresie, gdy kształtowała się koncepcja Ligi Narodów, ale też w późniejszych latach jej działalności, do grona jej admiratorów należał Oskar Halecki, pełniący najpierw funkcję sekretarza generalnego Biura Prac Kongresowych utworzonego przy Ministerstwie Spraw Zagranicznych w listopadzie 1918 r., oficjalnego organu pomocniczego delegacji polskiej na Konferencję Pokojową w Paryżu, a następnie m.in. Delegata Biura Propagandy Zagranicznej przy Sekretariacie Ligi, pracownika Sekretariatu Ligi, Sekretarza Międzynarodowej Komisji Współpracy Intelektualnej Ligi. Nawet po rozwiązaniu Ligi, oceniając Ligę Narodów z perspektywy historycznej, nie podważał sensu jej utworzenia i uważał, że całkowite dyskredytowanie jej działalności nie jest słuszne. Na pozytywną ocenę jego zdaniem zasługiwały relacje pomiędzy Polską a Ligą Narodów w latach 20. XX w. ${ }^{10}$

W gronie polskich polityków i dyplomatów okresu międzywojennego byli też tacy, którzy wyrażali krytyczne opinie na temat roli Ligi Narodów jako organizacji działającej na rzecz zapewnienia światowego pokoju. Sceptycznie odnosił się do niej Józef Piłsudski, uważając, że będzie ona instrumentem stworzonym przez wielkie mocarstwa $w$ celu realizacji ich własnej polityki. Kolejne lata działalności Ligi Narodów, brak możliwości skutecznego zapobiegania sporom międzynarodowym oraz zaangażowania $\mathrm{w}$ ich prawidłowe rozwiązywanie spowodował, że wśród polskich polityków i dyplomatów stopniowo poszerzał się krąg osób krytycznie oceniających Ligę Narodów ${ }^{11}$.

9 Cyt. za: B. Winiarski, Co z Ligą Narodów?, Ruch Prawniczy, Ekonomiczny i Socjologiczny 1936, drugie półrocze, R. 16, s. 212.

10 A.M. Brzeziński, Oskar Halecki a Liga Narodów. Poglady i działalność, Łódź 2016, s. 302-315.

11 Szerzej na ten temat W. Michowicz, Ewolucja stanowiska Polski wobec Ligi Narodów w okresie międzywojennym, w: Polska wobec idei integracji europejskiej w latach 1918-1945. Zbiór studiów, red. M. Wojciechowski, Toruń 2000, s. 5-26. 


\section{Uzyskanie przez Polskę statusu członka pierwotnego Ligi Narodów}

Sprawy członkostwa w Lidze Narodów zostały uregulowane w art. 1 Paktu Ligi. Postanowienia tego artykułu odnoszą się zarówno do nabycia członkostwa, jak i jego ustania w wyniku wystąpienia. Sprawa wykluczenia $\mathrm{z}$ Ligi została natomiast przewidziana $\mathrm{w}$ art. 16 jako sankcja za złamanie zobowiązań wynikających z Paktu.

W kwestii uzyskania członkostwa Pakt Ligi przewidywał członkostwo pierwotne oraz przyjęcie w poczet członków tej organizacji ${ }^{12}$. Polska uzyskała członkostwo pierwotne jako jedno z 32 państw-sygnatariuszy wymienionych w Aneksie załączonym do Paktu. Członkostwo pierwotne mogły uzyskać też państwa wymienione w Aneksie, należące do grupy 13 państw zaproszonych do przystąpienia, pod warunkiem złożenia przez nie deklaracji o przystąpieniu bez jakichkolwiek zastrzeżeń, w ciągu dwóch miesięcy od chwili wejścia w życie Paktu, oraz po notyfikowaniu tego faktu innym członkom Ligi. W odniesieniu do przyjęcia w poczet członków Ligi postanowiono nie ograniczać go wyłącznie do państw, przewidując możliwość przystąpienia do niej dominiów lub kolonii samodzielnie zarządzanych. Ustalono, że kandydat ubiegający się o członkostwo w Lidze powinien gwarantować przestrzeganie zobowiązań międzynarodowych oraz przyjąć ustalone przez Ligę uregulowania dotyczące sił zbrojnych i zbrojeń. Organem decydującym o przyjęciu w poczet członków było Zgromadzenie, w którym trzeba było uzyskać większość dwóch trzecich głosów.

Członek, który decydował się na wystąpienie z Ligi, był zobowiązany do zawiadomienia o tym zamiarze organizacji oraz wypełnienia wszystkich swoich zobowiązań i zobowiązań wynikających z Paktu, przy czym zawiadomienie powinno nastąpić dwa lata przed wystąpieniem z Ligi.

Skład członkowski Ligi Narodów podlegał zmianom wynikającym z przyjmowania nowych członków, jak też w związku z dużą liczbą przypadków występowania z organizacji. W pierwszym posiedzeniu Zgromadzenia Ligi w Genewie uczestniczyli reprezentanci 42 członków. Liga nie uzyskała nigdy przymiotu uniwersalnej organizacji międzynarodowej,

12 M.O. Hudson, Membership in the League of Nations, American Journal of International Law 1924, t. 18, nr 43, s. 436-442. 
który posiada obecnie Organizacja Narodów Zjednoczonych ${ }^{13}$. Największą liczebność osiągnęła Liga w 1935 r., gdy należało do niej 60 członków ${ }^{14}$. Niektóre państwa stosunkowo krótko były członkami Ligi, np. Niemcy wstąpiły do Ligi w 1926 r., a wystąpiły z niej w 1933 r., Związek Radziecki był członkiem od 1934 r. do 1939 r., gdy został wykluczony z Ligi. Z Ligi wystąpiły Japonia (w 1933 r.) i Włochy (w 1937 r.). Można zaważyć, że polskie władze państwowe też rozważały sprawę wystąpienia $z$ Ligi $^{15}$. Mimo jednak krytycznego stosunku do organizacji Polska pozostała członkiem Ligi do czasu jej rozwiązania.

\section{Przedstawicielstwo Polski przy Lidze Narodów}

Utworzenie Ligi Narodów spowodowało rozwój nowej formy przedstawicielstw dyplomatycznych, ustanawianych przez państwa przy organizacjach międzynarodowych. Przedstawicielstwa te, określane mianem stałych delegacji, umożliwiały utrzymywanie regularnych kontaktów z organizacją, istotnych ze względu na szeroki zakres działalności Ligi Narodów ${ }^{16}$. Polska była pierwszym państwem, które ustanowiło przy Lidze Narodów swojego stałego przedstawiciela ${ }^{17}$. Delegacja RP przy Lidze Narodów rozpoczęła działalność w listopadzie 1920 r. Funkcję delegatów powierzano wybitnym politykom i dyplomatom, którzy wspierali podczas posiedzeń Zgromadzenia i Rady polskich ministrów spraw zagranicznych ${ }^{18}$. Delegatami Polski przy Lidze byli: Ignacy Paderewski (15 listopada 1920 r. - 10 czerwca 1921 r.), Szymon Askenazy (15 listopada 1921 r. - 11 lipca 1923 r.), Konstanty Skirmunt (11 lipca 1923 r. 6 maja 1924 r.), Aleksander Skrzyński (6 maja 1924 r. - 3 marca 1925 r.),

13 T.D. Grant, Universality versus Coherence. Membership, Participation and Crisis of the League of Nations, International Community Law Review 2015, t. 17, nr 2, s. 171-173.

14 L. Ehrlich, Prawo międzynarodowe, wyd. 4, Warszawa 1958, s. 321.

15 W. Balcerak, Liga Nadziei. Z dziejów Ligi Narodów, Warszawa 2010, s. 174.

16 G. Grabowska, Reprezentacja Polski w organizacjach międzynarodowych. Problemy prawne, Warszawa 1990, s. 19.

17 P.B. Potter, Permanent Delegations to the League of Nations, American Political Science Review 1931, t. 25, nr 1, s. 26.

18 W. Michowicz, Organizacja polskiego aparatu dyplomatycznego w latach 1918-1939, w: Historia dyplomacji polskiej, t. 4: 1918-1939, red. P. Łossowski, Warszawa 1995, s. 23. 
Kajetan Dzierżykraj-Morawski (3 marca 1925 r. - 7 grudnia 1925 r.), Franciszek Sokal (14 stycznia 1926 r. - 31 marca 1932 r.), Tadeusz Gwiazdoski (1 kwietnia 1932 r. - 8 listopada 1932 r.), Edward Raczyński (8 listopada 1932 r. - 22 listopada 1934 r.), Tytus Komornicki (od 22 listopada 1934 r.) $)^{19}$. Liczba osób wchodzących w skład Delegacji RP ulegała zmianom, ale utrzymywała się w porównaniu z delegacjami innych członków na wysokim poziomie. W $1931 \mathrm{r}$. w do jej pięcioosobowego składu należeli: stały delegat, radca, attaché honorowy, attaché legacji i szef biura prasowego ${ }^{20}$. Do zadań Delegacji oprócz wspierania uczestnictwa Polski w posiedzeniach Zgromadzenia i Rady Ligi należało prowadzenie działalności sprawozdawczej, głównie dotyczącej spraw politycznych, ekonomicznych, mniejszościowych, emigracyjnych, kulturalnych, prasowych, organizacyjnych, rachunkowo-kasowych oraz utrzymywanie kontaktów z miejscowymi władzami i placówkami innych państw. W związku z pogorszeniem stosunków między Polską a Ligą Narodów i coraz bardziej krytyczną oceną w Polsce działalności organizacji w lipcu 1938 r. minister J. Beck zapowiedział zakończenie działalności Delegacji RP przy Lidze Narodów. Nastąpiło to 31 października 1938 r., a kompetencje Delegacji powierzono utworzonemu 1 listopada 1938 r. konsulatowi generalnemu w Genewie ${ }^{21}$. W następnych latach zadanie utrzymywania kontaktów z Ligą Narodów powierzano przebywającym w Genewie dyplomatom: Sylwinowi Strakaczowi (1939 r.) i Stanisławowi Albrechtowi Radziwiłłowi (lata 1940-1945).

Podkreślając prekursorską rolę Polski w zakresie kształtowania praktyki polegającej na ustanawianiu stałych przedstawicielstw dyplomatycznych przy organizacjach międzynarodowych, można zauważyć, że idąc za polskim przykładem, inni członkowie Ligi tworzyli tego rodzaju placówki, a ich liczba w połowie lat 30. wynosiła 37. Różniły się one pod względem składu, usytuowania, pełnionych funkcji ${ }^{22}$. Niektóre państwa, zaliczane w Lidze do grona mocarstw, nie podjęły takiej inicjatywy, prawdopodobnie uznając, że nawet nie posiadając tego rodzaju reprezentacji, mają silną pozycję w organizacji i duży wpływ na jej działalność. Niekiedy

19 Liga Narodów, Rocznik Służby Zagranicznej Rzeczypospolitej Polskiej według stanu na 1 kwietnia 1938 r. Ministerstwo Spraw Zagranicznych (1918-1938), Warszawa 1938, s. 161.

20 S. Sierpowski, Liga Narodów w najlepszym czasie (1926-1929), Poznań 2018, s. 77.

21 A.M. Brzeziński, Liga Narodów w koncepcjach i dyplomacji Józefa Becka (1932-1938), w: Płk Józef Beck (1894-1944). Żotnierz, dyplomata, polityk, red. S.M. Nowinowski, Łódź-Warszawa 2017, s. 107-108.

22 P.B. Potter, Permanent Delegations to the League of Nations..., s. 30-37. 
też powierzano kierowanie delegacjami przy Lidze szefom misji dyplomatycznych mających siedziby w Paryżu, Londynie, Bernie, a nawet w Rzymie i Madrycie ${ }^{23}$.

\section{Udział Polski w organach Ligi Narodów}

Członkostwo w Lidze Narodów wiązało się zarówno z obecnością Polski i jej przedstawicieli w różnych gremiach Ligi, jak i z rozpatrywaniem polskich spraw oraz przedstawianiem polskich inicjatyw na forum tej organizacji.

Głównymi organami Ligi były: Zgromadzenie, Rada i Sekretariat. W skład Zgromadzenia wchodzili przedstawiciele wszystkich członków Ligi. Polska, tak jak pozostali członkowie tej organizacji, mogła być reprezentowana $\mathrm{w}$ Zgromadzeniu maksymalnie przez trzech przedstawicieli i przysługiwał jej jeden głos. Pierwsze posiedzenie Zgromadzenia Ligi odbyło się w Genewie w dniach od 15 listopada do 18 grudnia 1920 r. Wśród osobistości świata politycznego uczestniczących w tym posiedzeniu był Jan Ignacy Paderewski ${ }^{24}$. Podczas posiedzenia przyjęto regulamin prac i zasady funkcjonowania Zgromadzenia ${ }^{25}$. Ustalono coroczne zwoływanie posiedzeń Zgromadzenia (ustalając pierwszy poniedziałek września jako termin ich rozpoczynania, z możliwością zmiany tego terminu podczas poprzedniego posiedzenia lub na mocy decyzji większości członków Rady). Zgromadzenie mogło też odbywać sesje nadzwyczajne zwoływane na wniosek każdego członka Ligi, poparty przez większość członków organizacji. Na forum Zgromadzenia można było rozpatrywać wszystkie sprawy objęte zakresem działania Ligi lub dotyczące pokoju na świecie. Zgromadzenie podejmowało uchwały i przyjmowało zalecenia. Do jego kompetencji należało uchwalanie budżetu Ligi i ustalanie w nim udziału poszczególnych członków. Zgromadzenie dokonywało też wyboru niestałych członków Rady.

23 S. Sierpowski, Liga Narodów w najlepszym czasie (1926-1929)..., s. 76.

24 S. Sierpowski, Narodziny Ligi Narodów..., s. 235. Ignacy Jan Paderewski uświetnił pierwsze posiedzenie Zgromadzenia uroczystym koncertem zorganizowanym w budynku Hotel National, w którym toczyły się obrady.

25 Rules of Procedure of the Assembly, November 30, 1920, The First Assembly of the League of Nations, A League of Nations 1921, t. 4, nr 1 (Double Number), s. 31-39. 
Sprawa składu Rady była dość złożoną kwestią, a dla Polski istotne znaczenie miały jej starania o uzyskanie $\mathrm{w}$ niej stałego miejsca. W myśl art. 4 Paktu Ligi w skład Rady wchodzili przedstawiciele członków stałych, którymi były główne mocarstwa (w latach 1920-1926 Francja, Wielka Brytania, Włochy i Japonia) oraz przedstawiciele czterech członków niestałych wyznaczanych przez Zgromadzenie, dla których czas trwania kadencji nie został w Pakcie określony. Kwestie dotyczące ustalania składu Rady były przedmiotem poważnych kontrowersji, licznych sporów i politycznych starań zarówno w okresie poprzedzającym przyjęcie Paktu, jak i w czasie działalności Ligi ${ }^{26}$. Należy przypomnieć, że inauguracyjna sesja Rady została zwołana przez amerykański Departament Stanu do Paryża na dzień 16 stycznia 1920 r., chociaż Stany Zjednoczone Ameryki pozostały w Radzie tzw. „wielkim nieobecnym” ${ }^{27}$. Skład Rady ulegał też licznym zmianom, zwłaszcza w stosunku do liczby przedstawicieli członków niestałych, ich liczbę bowiem zwiększano w celu załagodzenia sporów: w 1923 r. - do sześciu, w 1926 r. - do dziewięciu, w 1933 r. - do dziesięciu i w 1936 r. - do jedenastu ${ }^{28}$. Z punktu widzenia Polski szczególne znaczenie miało przyznanie stałego miejsca w Radzie dla przedstawiciela Niemiec, które zostały członkiem Ligi w 1926 r. Skłoniło to Polskę do podjęcia starań o uzyskanie stałego miejsca dla jej reprezentanta. Wobec aspirowania o takie miejsce także innych państw (np. Brazylii) powołano komisję, a następnie Podkomitet Siedmiu w celu opracowania nowego statutu Rady. Efektem prac Podkomitetu było ustanowienie w Radzie miejsc półstałych, które mogły być obsadzane przez te same państwa w drodze kolejnych wyborów po zakończeniu trzyletniej kadencji ${ }^{29}$. W związku z tym Polska była przez wiele lat członkiem Rady do czasu, gdy sama w 1938 r. zrezygnowała z ubiegania się o wybór na następną kadencję ${ }^{30}$.

Warto zauważyć, że powierzając kompetencje Radzie, posłużono się w Pakcie Ligi Narodów takim samym określeniem jak w odniesieniu do

26 D.P. Myers, Representation in League of Nations Council, American Journal of International Law 1926, t. 20, nr 4, s. 689-699.

27 S. Sierpowski, Narodziny Ligi Narodów..., s. 212-213. W pierwszym roku działalności Ligi odbyło się jedenaście sesji Rady, organizowanych głównie w Paryżu i Londynie. Także w kolejnych latach większość sesji miała miejsce poza Genewą. Dopiero od 1926 r. prowadzono je w siedzibie Ligi Narodów w Genewie.

28 S. Sierpowski, Liga Narodów w najlepszym czasie (1926-1929)..., s. 74.

29 W. Balcerak, Liga Nadziei..., s. 174-175.

30 A.M. Brzeziński, Liga Narodów w koncepcjach i dyplomacji Józefa Becka (1932-1938)..., s. 107. 
Zgromadzenia i postanowiono, że Rada "rozpoznaje wszystkie sprawy wchodzące w zakres działania Ligi lub dotyczące pokoju świata" (art. 4 ust. 4 Paktu Ligi). W dalszych postanowieniach Paktu wskazano jednak w sposób bardziej szczegółowy jej funkcje. Rada zajmowała się sprawami rozbrojenia i kontrolowała wykonywanie mandatów. Zatwierdzała nominacje w Sekretariacie Ligi dokonywane przez Sekretarza Generalnego. Miała też prawo podejmowania interwencji w sprawach zapewnienia ochrony mniejszości narodowych. Poza tym Rada mianowała członków komisji, której powierzony był zarząd nad odłączonym od Rzeszy terytorium Zagłębia Saary, mianowała Wysokiego Komisarza w Gdańsku i zajmowała się sporami tego miasta z Polską.

Na forum Rady było rozpatrywanych wiele spraw dotyczących Polski, a niektóre z nich były też rozstrzygane na drodze sądowej. Już w pierwszych miesiącach działalności Ligi zajmowano się w Radzie sporem polsko-litewskim dotyczącym Wileńszczyzny (od września 1920 r. do stycznia 1922 r.). Często przedmiotem posiedzeń Rady były sprawy Wolnego Miasta Gdańska, które wymagały od polskiej dyplomacji wielu wysiłków skierowanych na egzekwowanie praw Polski w odniesieniu do tego terytorium. W latach 1922-1933 Rada Ligi rozpatrzyła 106 spraw spornych między Rzecząpospolitą a Gdańskiem.

Trzecim głównym organem Ligi był Sekretariat. Został on utworzony jako organ o charakterze technicznym, który miał wspierać działalność Zgromadzenia i Rady. W rzeczywistości rola Sekretariatu została znacznie poszerzona. Przygotowywał on materiały na sesje Zgromadzenia i Rady, opracowywał projekty uchwał, zapewniał obsługę prac różnych komisji i konferencji międzynarodowych. W okresie istnienia Ligi było trzech sekretarzy generalnych: pierwszym z nich, którego nazwisko zostało wymienione w Pakcie, był Brytyjczyk James Eric Drummond, pełniący tę funkcję w latach 1920-1933, a następnymi byli: Francuz Joseph Avenol (1933-1940) i Irlandczyk Seán Lester (1940-1946). Dla Polski i innych członków Ligi ważną kwestią była sprawa obsady stanowisk w Sekretariacie. W początkowym okresie działalności organizacji zdecydowanie dominowali pracownicy pochodzący z państw należących do grona ligowych mocarstw - w 1922 r. zajmowali oni 75\% najważniejszych stanowisk w Sekretariacie ${ }^{31}$. Wielu jego pracowników było wcześniej związanych z działalnością akademicką (nieco sarkastycznie mówiono

\footnotetext{
31 S. Sierpowski, Liga Narodów w latach 1919-1926, Wrocław-Warszawa-Kraków 2005, s. 54.
} 
o „Lidze profesorów”). W następnych latach powiększył się stan zatrudnienia (w 1931 r. osiągnął najwyższy poziom - 707 osób), a także wzrosła w nim liczba zawodowych dyplomatów. W Sekretariacie Ligi wyraźnie ujawnił się też problem zapewnienia niezależności pracujących $\mathrm{w}$ nim osób od państw ich pochodzenia oraz traktowania spełnianej przez nie roli jako działalności funkcjonariuszy międzynarodowych ${ }^{32}$.

W ramach Ligi Narodów powoływano też liczne komisje, którym powierzano różne zadania. Utworzono stałe komisje czuwające nad sprawami podlegającymi Lidze: Komisję ds. Wolnego Miasta Gdańska, Komisję Mandatową i Komisję ds. Mniejszości Narodowych. Powołano też instytucje koordynujące współpracę międzynarodową w dziedzinie kultury, gospodarki i pomocy humanitarnej. Ważną działalność prowadziło Biuro Komisarza Ligi Narodów ds. Uchodźców.

Przedstawiając udział Polski w strukturach organizacyjnych Ligi, należy też wspomnieć o Stałym Trybunale Sprawiedliwości Międzynarodowej. Nie był on organem Ligi, ale pozostawał z nią w bardzo bliskich związkach, począwszy od sprawy jego utworzenia, poprzez ustalanie składu sędziowskiego, aż po wypełniane przez niego funkcje. W art. 14 Paktu Ligi zobowiązano Radę do przygotowania projektu statutu trybunału i przedstawienia go członkom Ligi. Rada 13 lutego 1920 r. powołała Komitet Prawników, złożony z dziesięciu ekspertów, który opracował projekt statutu. Projekt ten, po wniesieniu poprawek przez Radę, został przedstawiony Zgromadzeniu, które przyjęło Statut na mocy rezolucji jednogłośnie uchwalonej 13 grudnia 1920 r. ${ }^{33}$ Tekst Statutu został dołączony do Protokołu z 16 grudnia 1920 r., otwartego do podpisu dla państw członkowskich Ligi i wskazanych w Aneksie do Paktu ${ }^{34}$. Polska złożyła dokument ratyfikacyjny Protokołu 26 sierpnia $1921 \mathrm{r} .{ }^{35}$ Statut wszedł w życie 1 września 1921 r., a 15 lutego 1922 r. Trybunał rozpoczął działalność. Zgodnie z art. 8 Statutu do kompetencji Zgromadzenia i Rady

32 Tamże, s. 55.

33 Szerzej na temat prac nad Statutem Trybunału M.O. Hudson, The Permanent Court of International Justice, Harvard Law Review 1921-1922, t. 35, nr 3, s. 246-249.

34 Statut Stałego Trybunału Sprawiedliwości Międzynarodowej, przewidzianego w artykule 14 Paktu Ligi Narodów, Genewa, 16 grudnia 1920 r., Dz. U. z 1923 r. Nr 106, poz. 839.

35 Oświadczenie rządowe z dnia 26 lipca 1923 r. w przedmiocie złożenia dokumentu ratyfikacyjnego Protokołu podpisania Statutu Stałego Trybunału Sprawiedliwości Międzynarodowej z dnia 16 grudnia 1920 r., Dz. U. z 1923 r. Nr 106, poz. 840. Polska złożyła też 24 stycznia 1931 r. deklarację o uznaniu obligatoryjnej jurysdykcji Trybunału. 
Ligi należał wybór sędziów Trybunału, dokonywany przez te organy w drodze niezależnych głosowań. Warunkiem wyboru było uzyskanie przez kandydata na sędziego bezwzględnej większości głosów w obu organach. W skład Trybunału wchodziło początkowo jedenastu sędziów, a 1936 r. ich liczbę powiększono do piętnastu. W pierwszym składzie sędziowskim ustalonym we wrześniu 1921 r. nie było polskiego sędziego, natomiast 25 września 1930 r. został wybrany do Trybunału Michał Cezary Rostworowski, który zasiadał w nim w latach 1931-1939. Niekorzystnym aspektem relacji Polski z Trybunałem był natomiast fakt, że Polska była państwem, które ze względu na dużą liczbę spraw spornych, najczęściej - dziewięć razy - występowało w charakterze strony sporu przed Trybunałem. Była też najczęściej - jedenaście razy - tzw. państwem zainteresowanym $\mathrm{w}$ postępowaniach $\mathrm{w}$ sprawie wydania opinii doradczych, o które zwracały się do Trybunału Zgromadzenie i Rada ${ }^{36}$. Rozpatrywane przez Trybunał sprawy dotyczyły głównie stosunków polsko-niemieckich i Wolnego Miasta Gdańska, a rozstrzygnięcia, które w nich zapadały, były w większości dla Polski niekorzystne ${ }^{37}$. W latach 1922-1940 Stały Trybunał Sprawiedliwości Międzynarodowej rozpatrzył 29 spraw spornych i wydał 27 opinii doradczych.

\section{Stosunek Polski do działalności na forum Ligi Narodów}

Stosunek Polski do Ligi Narodów ulegał zmianom w okresie ponad dwudziestoletniej jej obecności w organizacji jako państwa członkowskiego. Istotny wpływ na te relacje miało stanowisko władz państwowych, w tym także kierownictwa resortu spraw zagranicznych, wobec działań podejmowanych przez organy Ligi. Można też zauważyć, że w pierwszych latach po odzyskaniu przez Polskę niepodległości następowały częste zmiany na stanowisku ministra spraw zagranicznych. Funkcję tę pełnili od 11 listopada 1918 r. do 15 maja 1926 r.: Tytus Filipowicz, Leon

36 J. Sutor, Pokojowe załatwianie sporów międzynarodowych, Wrocław-Warszawa-Kraków-Gdańsk 1979, s. 176-177.

37 A. Potyrała, Polska przed Stałym Trybunałem Sprawiedliwości Międzynarodowej, w: Polska w instytucjach międzynarodowych w latach 1918-2018, red. E. Haliżak, T. Łoś-Nowak, A. Potyrała, J. Starzyk-Sulejewska, Warszawa 2019, s. 171-173. 
Wasilewski, Ignacy Jan Paderewski, Władysław Wróblewski, Stanisław Patek, Eustachy Sapiecha, Jan Dąbski, Konstanty Skirmunt, Gabriel Narutowicz, Aleksander Skrzyński (dwukrotnie), Marian Seyda, Roman Dmowski, Karol Bertoni, Maurycy Zamoyski, Kajetan Dzierżykraj-Morawski, z tym że w wypadku niektórych osób okres sprawowania tej funkcji trwał tylko kilka dni ${ }^{38}$. Dłużej ministrem spraw zagranicznych był Aleksander Skrzyński (16 grudnia 1922 r. - 26 maja 1923 r. i 27 lipca 1924 r. 5 maja 1926 r.). W okresie kierowania przez niego resortem Polska wykazywała się dużą aktywnością na forum Ligi. Było to związane z przyjęciem przez A. Skrzyńskiego koncepcji, że zachowanie pokoju i umacnianie bezpieczeństwa powinno być oparte na Lidze Narodów i jej systemie międzynarodowego bezpieczeństwa. Zaangażował się też w prace nad Protokołem genewskim w sprawie pokojowego rozwiązywania sporów, dlatego nieprzyjęcie dokumentu uznał za porażkę i poważny błąd członków Ligi. Uważał, że wobec niemożności zapobieżenia zawarciu Układu w Locarno, niekorzystnego z punktu widzenia Polski, jej dyplomacja powinna starać się minimalizować jego negatywne konsekwencje.

Następca A. Skrzyńskiego na stanowisku ministra spraw zagranicznych August Zalewski sprawował tę funkcję od 15 maja 1926 r. do 2 listopada 1932 r. Polska kontynuowała podjęte w 1925 r. prace w Komisji Przygotowawczej Konferencji Rozbrojeniowej, opowiadając się za francuską koncepcją rozbrojenia. Zgodnie z tą koncepcją w pierwszej kolejności należało zapewnić państwom bezpieczeństwo, a dopiero później podejmować działania na rzecz rozbrojenia, które powinno być przeprowadzane etapami na podstawie regionalnych porozumień między państwami. W 1927 r. polski delegat Franciszek Sokal na forum Zgromadzenia Ligi przedstawił projekt rezolucji dotyczącej „uroczystej deklaracji o nieagresji" przewidującej wyrzeczenie się wojny jako narzędzia rozstrzygania sporów międzynarodowych, która nie zyskała jednak aprobaty państw. Zgłoszona podczas kolejnej sesji Zgromadzenia polska propozycja w sprawie zakazu wojny napastniczej została przyjęta 24 września 1928 r. ${ }^{39}$ Była ona

38 Ministerstwo Spraw Zagranicznych II Rzeczypospolitej. Organizacja, polityka, ministrowie, red. P. Długołecki, K. Szczepanik, Warszawa 2014, s. 95-280.

39 Z.B. Rudnicki, Polska w Lidze Narodów; kwestie bezpieczeństwa i rozstrzygania sporów międzynarodowych, w: Polska winstytucjach międzynarodowych w latach 1918-2018, red. E. Haliżak, T. Łoś-Nowak, A. Potyrała, J. Starzyk-Sulejewska, Warszawa 2019, s. 126-128. 
zbieżna z postanowieniami Traktatu przeciwwojennego - Paktu Brianda-Kellogga z 27 sierpnia 1928 r. $^{40}$

Na początku lat 30. Polska przedstawiła na forum Ligi koncepcję rozbrojenia moralnego, której twórcą był gen. Tadeusz Kasprzycki, zakładającą dobrowolne działanie państw na rzecz wyeliminowania ze stosunków międzynarodowych ducha nienawiści i przemocy, przestrzegania traktatów międzynarodowych i rozwijania różnych form współpracy międzynarodowej ${ }^{41}$.

Na szczególnie trudny okres przy padło kierowanie resortem spraw zagranicznych przez Józefa Becka (od 2 listopada 1932 r. do 30 września 1939 r.). Będąc bliskim współpracownikiem Józefa Piłsudskiego, krytycznie odnoszącego się do Ligi Narodów, spowodował też zmianę stanowiska polskiej dyplomacji wobec tej organizacji i działań na jej forum. Polskie ministerstwo spraw zagranicznych nie wierzyło w możliwości efektywnego oddziaływania Ligi na sprawy bezpieczeństwa międzynarodowego, wskazując na takie wydarzenia jak: agresja Włoch wobec Abisynii, odrzucenie przez Rzeszę części postanowień traktatu wersalskiego, remilitaryzacja Nadrenii. Zmiana stosunku do Ligi spowodowała, że starano się uzyskać gwarancje bezpieczeństwa poprzez zawieranie z innymi państwami dwustronnych porozumień. Zdecydowanym aktem polskiej dyplomacji było zawieszenie przez Polskę 13 września 1934 r. stosowania międzynarodowej procedury z udziałem organów Ligi Narodów w sprawach ochrony mniejszości narodowych, przewidzianych w art. 12 tzw. małego traktatu wersalskiego, określanego też mianem traktatu mniejszościowego ${ }^{42}$.

Należy zauważyć, że kryzys zaufania do Ligi Narodów poszerzał się wśród jej członków i spowodował podjęcie na forum Ligi prac zmierzających do reformy organizacji ${ }^{43}$. Polska dyplomacja także włączyła się

40 Traktat przeciwwojenny (Traktat o wyrzeczeniu się wojny - druga oficjalna nazwa), Paryż, 28 sierpnia 1928 r., Dz. U. z 1929 r. Nr 63, poz. 489. Por. też W. Balcerak, Liga Nadziei..., s. 178-179.

41 Tamże, s. 180-181.

42 Traktat między Głównemi Mocarstwami sprzymierzonemi i stowarzyszonemi a Polską, podpisany w Wersalu dnia 28 czerwca 1919 r., Dz. U. z 1920 r. Nr 110, poz. 278. Por. na ten temat T. Kulak, Polska wobec Ligi Narodów w latach 1935-1936, w: Polska wobec idei integracji europejskiej w latach 1918-1945. Zbiór studiów, red. M. Wojciechowski, Torun 2000, s. 31-32; K. Kania, Edward Bernard Raczyński 1891-1993 dyplomata i polityk, Warszawa 2014, s. 85.

43 Wnikliwą analizę na temat możliwości reformy Ligi Narodów i jej możliwości adaptacji do zmieniającego się środowiska międzynarodowego przedstawił C. Mik, The League 
do działań, przesyłając 10 grudnia 1936 r. w tej sprawie memorandum. Podkreślono w nim potrzebę urzeczywistnienia zasady powszechności organizacji i uznawania zasady suwerenności państw za fundament działania Ligi. Zaznaczono też, iż jeśli organizacja funkcjonuje na zasadzie jednomyślności, to należy $\mathrm{w}$ niej przestrzegać też zasady nieingerencji w sprawy wewnętrzne państw. Krytycznie odniesiono się do nadmiernego wzmocnienia roli Sekretariatu Ligi ${ }^{44}$.

Zmiany w stanowisku Polski wobec Ligi odzwierciedla stwierdzenie zawarte $\mathrm{w}$ instrukcji ministra spraw zagranicznych Józefa Becka z 8 maja 1936 r.:

Wiara w rolę Paktu Ligi Narodów jako instrumentu kolektywnego bezpieczeństwa załamała się ostatecznie wobec oczywistej nieskuteczności systemu sankcyjnego, opartego jedynie na presji gospodarczo-społecznej ${ }^{45}$.

Bardziej zdecydowanie określił swój stosunek do Ligi podczas konferencji dyrektorów MSZ 4 listopada 1938 r.:

Liga Narodów umarła. Jednocześnie z nią skompromitował się w sposób gwałtowny tzw. system francuski w Europie Wschodniej, jak również skuteczność kombinowanych wystąpień francusko-angielskich, którym na tle Ligi chciano nadać charakter zbliżony do wyroków trybunału międzynarodowego ${ }^{46}$.

Na kilka miesięcy przed agresją Niemiec na Polskę minister J. Beck stwierdził, że nie należy kontynuować dotychczasowej polityki w Lidze Narodów, członkostwo $\mathrm{w}$ tej organizacji bowiem krępuje poczynania państwa polskiego, a nie przynosi spodziewanych efektów ${ }^{47}$.

of Nation's Capacity for Reform and Adaptation, International Community Law Review 2015, t. 17, nr 2, s. 189-215.

44 A.M. Brzeziński, Liga Narodów w koncepcjach i dyplomacji Józefa Becka (1932-1938)..., s. $100-101$.

45 Diariusz i teki Szembeka (1935-1945), t. 2: Uzupetnienia do dokumentacji tomu pierwszego, Londyn 1965, cyt. za W. Balcerak, Liga Nadziei..., s. 183.

46 Diariusz i teki Szembeka (1935-1945), t. 4: Diariusz i dokumentacja za rok 1938, diariusz i dokumentacja za rok 1939, Londyn 1972, cyt. za W. Balcerak, Liga Nadziei..., s. 183.

47 J. Beck, Przemówienia, deklaracje, wywiady 1931-1939, Warszawa 1939, s. 271-272. 


\section{Zakończenie}

Zawierając Pakt Ligi Narodów, strony zobowiązały się do nieuciekania się do wojny, utrzymywania stosunków międzynarodowych opartych na sprawiedliwości i honorze, ścisłego przestrzegania prawa międzynarodowego, poszanowania sprawiedliwości i zobowiązań traktatowych. Jako cele organizacji wskazano stworzenie systemu bezpieczeństwa międzynarodowego, zapewnienie warunków pokojowego rozwiązywania sporów międzynarodowych i urzeczywistnianie stopniowego rozbrojenia. Zrealizowanie tych celów okazało się jednak niemożliwe. Liga nie miała odpowiednich organów wykonawczych, które mogłyby stanowić instytucjonalne podstawy zbiorowego bezpieczeństwa, nie dysponowała skutecznymi środkami nacisku w wypadku konfliktów, nie miała możliwości zastosowania sankcji wojskowych. Jej działania były w dużym stopniu podporządkowane interesom mocarstw, bez należytego uwzględniania praw mniejszych i słabszych państw. Wydaje się również, że pewnym obciążeniem dla Ligi było uznawanie Paktu Ligi za integralną część traktatów pokojowych. Mimo wielu poważnych porażek w działalności tej organizacji można odnotować też pewne sukcesy $\mathrm{w}$ regulowaniu niektórych spraw spornych, zapewnieniu ochrony apatrydom w postaci paszportów nansenowskich, zainicjowaniu działalności Stałego Trybunału Sprawiedliwości Międzynarodowej oraz Międzynarodowego Biura Pracy. Po wybuchu II wojny światowej Liga Narodów zaprzestała działalności, ale formalnie została rozwiązana 19 kwietnia 1946 r., gdy już od kilku miesięcy działała Organizacja Narodów Zjednoczonych.

W bogatym piśmiennictwie naukowym dotyczącym Ligi Narodów dominują krytyczne opinie na jej temat. $Z$ wielu prac wyłania się negatywna ocena tej organizacji. W krytycznych wypowiedziach używa się niekiedy w stosunku do niej dość oryginalnych określeń: fałszywy mesjasz, emancypantka-pozorantka, narzędzie segregacji państw, uzurpator i samozwańczy arbiter, eksperyment kamuflażu ${ }^{48}$. W sposób bardziej stonowany mówi się o niej jako o strażniczce interesów Zachodu, rezultacie gry przeciwstawnych interesów społeczności narodowych,

48 A. Bógdał-Brzezińska, Zamiast zakończenia. Nieślubna córka świętego Mikołaja. Liga Narodów w krzywym zwierciadle teorii, w: Liga Narodów wybranych, red. M.F. Gawrycki, A. Bógdał-Brzezińska, Warszawa 2010, s. 201-210. 
instytucji, w której interesy zwycięzców starano się ukryć pod pozorami równouprawnienia, wolności i postępu ${ }^{49}$. Oprócz tych przeważających negatywnych opinii na temat roli Ligi Narodów, wyrażane są też poglądy, że przyczyniła się ona do ustalenia nowych standardów w relacjach międzynarodowych, była ważnym ogniwem $\mathrm{w}$ procesie instytucjonalizacji stosunków międzynarodowych, uzyskane bowiem dzięki jej działalności doświadczenia wykorzystano przy tworzeniu Organizacji Narodów Zjednoczonych ${ }^{50}$. Można zauważyć, że podobnie jak Liga Narodów, także niektóre współczesne organizacje międzynarodowe są obiektami poważnej krytyki. Zarzuca się im brak skuteczności lub zawłaszczanie kompetencji państw członkowskich, zapominając często o tym, w jaki sposób określono $\mathrm{w}$ statutach zakres i treść ich uprawnień i obowiązków, oraz nie biorąc pod uwagę faktu, że kluczowe znaczenie ma wola państw członkowskich nie tylko $\mathrm{w}$ ustanawianiu zasad postępowania, ale i w stosowaniu ich w praktyce międzynarodowej. Organizacje międzynarodowe nie są bowiem bytami całkowicie samodzielnymi, autonomicznymi i niezależnymi od państw ${ }^{51}$.

\section{Bibliografia}

Balcerak W., Liga Nadziei. Z dziejów Ligi Narodów, Warszawa 2010.

Beck J., Przemówienia, deklaracje, wywiady 1931-1939, Warszawa 1939.

Brzeziński A.M., Oskar Halecki a Liga Narodów. Poglady i działalność, Łódź 2016.

Brzeziński A.M., Liga Narodów w koncepcjach i dyplomacji Józefa Becka (1932-1938), w: Płk Józef Beck (1894-1944). Żotnierz, dyplomata, polityk, red. S.M. Nowinowski, Łódź-Warszawa 2017.

Ehrlich L., Prawo międzynarodowe, wyd. 4, Warszawa 1958.

Gawrycki M.F., Bógdał-Brzezińska A. (red.), Liga Narodów wybranych, Warszawa 2010.

Grabowska G., Reprezentacja Polski w organizacjach międzynarodowych. Problemy prawne, Warszawa 1990.

49 Tamże, s. 211-217.

50 J. Menkes, A. Wasilkowski, Organizacje międzynarodowe..., s. 116.

51 J. Symonides (red.), Wstęp, w: Organizacja Narodów Zjednoczonych. Bilans i perspektywy, Warszawa 2006, s. 14. 
Grant T.D., Universality versus Coherence. Membership, Participation and Crisis of the League of Nations, International Community Law Review 2015, t. 17, nr 2.

Hudson M.O., The Permanent Court of International Justice, Harvard Law Review 1921-1922, t. 35, nr 3.

Hudson M.O., Membership in the League of Nations, American Journal of International Law 1924, t. 18, nr 43.

Kania K., Edward Bernard Raczyński 1891-1993 dyplomata i polityk, Warszawa 2014.

Kulak T., Polska wobec Ligi Narodów w latach 1935-1936, w: Polska wobec idei integracji europejskiej w latach 1918-1945. Zbiór studiów, red. M. Wojciechowski, Toruń 2000.

Lesiewicz E., Stachowiak P., Polska wizja Ligi Narodów, w: Polska w instytucjach międzynarodowych w latach 1918-2018, red. E. Haliżak, T. Łoś-Nowak, A. Potyrała, J. Starzyk-Sulejewska, Warszawa 2019.

Menkes J., Wasilkowski A., Organizacje międzynarodowe. Prawo instytucjonalne, Warszawa 2017.

Michowicz W., Ewolucja stanowiska Polski wobec Ligi Narodów w okresie międzywojennym, w: Polska wobec idei integracji europejskiej w latach 1918-1945. Zbiór studiów, red. M. Wojciechowski, Torun 2000.

Michowicz W., Polska w Lidze Narodów, Sprawy Międzynarodowe 1978, nr 12.

Michowicz W., Organizacja polskiego aparatu dyplomatycznego w latach 1918-1939, w: Historia dyplomacji polskiej, t. 4: 1918-1939, red P. Łossowski, Warszawa 1995.

Mik C., The League of Nation's Capacity for Reform and Adaptation, International Community Law Review 2015, t. 17, nr 2.

Myers D.P., Representation in League of Nations Council, American Journal of International Law 1926, t. 20, nr 4.

Potter P.B., Permanent Delegations to the League of Nations, American Political Science Review 1931, t. 25, nr 1.

Potyrała A., Polska przed Stałym Trybunałem Sprawiedliwości Międzynarodowej, w: Polska w instytucjach międzynarodowych w latach 1918-2018, red. E. Haliżak, T. Łoś-Nowak, A. Potyrała, J. Starzyk-Sulejewska, Warszawa 2019.

Reginia-Zacharski J., Liga Narodów, w: Liga Narodów, ONZ, NATO, UE, KBWE/ OBWE, organizacje pozarzadowe, red. P. Żurawski vel. Grajewski, Łódź 2004.

Rudnicki Z.B., Polska w Lidze Narodów; kwestie bezpieczeństwa i rozstrzygania sporów międzynarodowych, w: Polska w instytucjach międzynarodowych w latach 1918-2018, red. E. Haliżak, T. Łoś-Nowak, A. Potyrała, J. Starzyk-Sulejewska, Warszawa 2019.

Sierpowski S., Narodziny Ligi Narodów. Powstanie, organizacja i zasady działania, Poznań 1984.

Sierpowski S., Geneza Ligi Narodów, Dzieje Najnowsze 1999, t. 31, nr 1.

SierpowskiS., Liga Narodów w latach 1919-1926, Wrocław-Warszawa-Kraków 2005. 
Sierpowski S., Liga Narodów w najlepszym czasie (1926-1929), Poznań 2018.

Sutor J., Pokojowe załatwianie sporów międzynarodowych, Wrocław-Warszawa-Kraków-Gdańsk 1979.

Winiarski B., Co z Ligq Narodów?, Ruch Prawniczy, Ekonomiczny i Socjologiczny 1936, drugie półrocze, R. 16, s. 208-220.

\section{Streszczenie}

Polska należała do pierwotnych członków Ligi Narodów, która rozpoczęła działalność sto lat temu - w 1920 r. Podstawę prawną funkcjonowania organizacji stanowił Pakt Ligi Narodów, włączony do traktatów pokojowych, zawartych po I wojnie światowej. Członkostwo w organizacji miało duże znaczenie dla odrodzonego państwa polskiego, które kształtowało swoje stosunki w społeczności międzynarodowej. Polska była pierwszym państwem, które ustanowiło przy Lidze swojego stałego delegata. Polscy przedstawiciele uczestniczyli w pracach głównych organów Ligi: Zgromadzeniu i Radzie. Polska starała się o uzyskanie stałego miejsca w Radzie, natomiast była w niej członkiem półstałym. Była też państwem, które często uczestniczyło w postępowaniach przed Stałym Trybunałem Sprawiedliwości Międzynarodowej. W latach 30. XX w. w kręgach polskiej dyplomacji wzrastało rozczarowanie działalnością Ligi Narodów spowodowane jej nieskutecznością w zakresie zapobiegania konfliktom międzynarodowym i rozwiązywania sporów międzynarodowych.

Słowa kluczowe: Liga Narodów, Pakt Ligi Narodów, organizacja międzynarodowa, członkostwo, organy Ligi Narodów, stałe przedstawicielstwo

\section{POLAND'S MEMBERSHIP IN THE LEAGUE OF NATIONS - LEGAL ASPECTS}

\section{Sum mary}

Poland belonged to the original members of the League of Nations, organization that began its activity a hundred years ago - in 1920. The legal basis for the organization's functioning was the Covenant of the League of Nations, incorporated into peace treaties concluded after the First World War. To a recently reborn Polish state aspiring to shape its relations in the international community, the membership in this organization was of great importance. Poland was the first state to establish the permanent delegation to the League of Nations. Polish representatives participated in the works of the main League's bodies: the Assembly 
and the Council. Poland sought to obtain a permanent seat in the Council, while it was a semi-permanent member there. Poland was also a state that often participated in proceedings before the Permanent Court of International Justice. However, in the 1930s, due to organization's ineffectiveness in preventing the international conflicts and resolving international disputes, has grown disappointment with the activities of the League of Nations among the Polish diplomacy.

Key words: the League of Nations, Covenant of the League of Nations, international organization, membership, bodies of the League of Nations, permanent delegation

\section{ЧЛЕНСТВО ПОЛЬШИ В ЛИГЕ НАЦИЙ - ПРАВОВЫЕ АСПЕКТЫ Резюме}

Польша была одним из первых членов Лиги Наций, которая начала свою деятельность сто лет назад - в 1920 году. Правовой основой функционирования организации был Пакт Лиги Наций, включенный в мирные договоры, заключенные после Первой мировой войны. Членство в организации имело большое значение для возрожденного польского государства, которое формировало отношения в международном сообществе. Польша была первой страной, назначившей постоянного представителя в Лиге. Польские представители участвовали в работе главных органов Лиги: Ассамблеи и Совета. Польша пыталась получить постоянное место в Совете, однако оставалась в нем полупостоянным членом. Являлась также страной, которая часто участвовала в разбирательствах в Постоянной палате международного правосудия. В 1930-х годах польская дипломатия все больше разочаровывалась в деятельности Лиги Наций из-за ее неэффективности в предотвращении международных конфликтов и разрешении международных споров.

Ключевые слова: Лига Наций, Пакт Лиги Наций, международная организация, членство, органы Лиги Наций, постоянное представительство 